\title{
UN MITO CULTURAL DEL NORTE DEL PERU
}

\author{
REBECa CarRión Cachot
}

\section{Generalidades}

Nuevos aspectos de las interrelaciones culturales y de las creencias religiosas de los antiguos pobladores del Norte del Perú van poniéndose en evidencia con el estudio comparativo de las manifestaciones artísticas de las culturas de esa área; y con la incorporación de materiales obtenidos por excavaciones científicas en lugares que fueron asiento de importantes culturas.

Trece mil doscientos cuarenta objetos, de tres períodos diferentes han sido exhumados de las Necrópolis de Ancón por el Museo Nacional de Antropología y Arqueología en los últimos cinco años. Estas valiosas fuentes de estudio unidas a las colecciones Chimú, Tallán y Muchik que posee el Museo, abren nuevas rutas a la investigación sobre el pasado del Jerúe Pu

La Bahía de Ancón fué ocupada permanentemente desde tiempos remotos hasta la época de los Incas. Los primeros establecimientos humanos corresponden a una colonia Chavín que se calcula en 3,000 años de antigüedad, la que da origen a una modalidad local bien definida, que pasa por diversas faces de desarrollo. En Ancón convergen varias corrientes culturales que se compenetran con las manifestaciones locales, o se mantienen puras sin mezclarse con aquellas.

El examen minucioso de los materiales hallados, me ha permitido descubrir elementos de culturas norteñas bien definidas que por expansión cultural o comercial se fusionaron a la local de Ancón. Se han encon'rado restos de la Cultura Chimú en una proporción de casi el $25 \%$; y también, de una cultura más septentrional que tal vez podría tener origen Chibcha; fuera de las influencias andinas de Huaylas, Inka y aun Tiahuanaco.

El material de mayor interés lo constituyen los objetos de carácter ritual q 10 acompañan a las momias, a través del cual es posible penetrar en el mundo misterioso de sus creencias y en la actitud del hombre frenty a acontecimientos o fenómenos que afectan su vida. 
Este trabajo tiene como objeto presentar los testimonios que prueban la existencia de un $\mathrm{M}$ i $\mathrm{t} \mathrm{o}$ en el Norte del Perú, común a todos los pueblos comprendidos en esa área, los que debteron por tanto tener lazos de pareniesco o sostuvieron relaciones culturales. Algunos cronistas como Sámaco-Xeres hacen referencia a una lingüística norteña en la que se hablaba un ídioma como "arábigo"; Cobo establece que había un límite lingüístico en el Valle de Lima hasta donde se hablaban las lenguas del Norte; Muchik y Quignan.

Morúa asimismo hace referencia a una quinta provincia que integraba el Imperio de los Inkas, y la denomina "Caiba" (Véase Morúa).

Estos datos son del mayor interés para el propósito de este tema, pues coinciden en el hecho de que el extremo septentrional formaba una unidad. La Arqueología por su parte, cuenta hoy con elementos suficientes para establecer que las culturas del Norte del Litoral, desde diversos puntos de vista, tienen caracteres propios, por ejemplo: los cadáveres son enterrados generalmente en posición horizontal, sobre taunas, y no en cuclillas como es lo usual; la arquitectura es diferente y la cerámica es monocroma, negra. Aun la influencia Inka en esta región es nula o muy superficial. Esta área es conocida con el nombre genérico del Gran Reino del Chimú; el que debió abarcar territorios más lejanos por la costa ecuatoriana.

Ahora bien, entre los materiales arqueológicos de Ancón figuran muchos elementos que están conectados con un Mito ampliamente desarrollado en el Norte del Litoral. Se trata de un mito cultural de hondo significado difundido desde Manabí por el Norte hasta Pachacamac por el Sur; y que se encuentra ampliamente contenido en las obras de arte de las culturas comprendidas en esa área; tanto en la cerámica como en los tejidos, en los objetos de piedra $y$ cun en las joyas de oro Y pirata, lo que da unidgd a estas imanifestacionesoartísticas.

Tiene como protagonista $a$ un Dios principal Ornitomorfo y $\alpha$ varios seres que le sirven de auxiliares. Dada la constante representación de los mismos personajes y de sus acciones, debió estar muy arraisado en la mentalidad popular. Por tradición oral o por medios nemónito pornue de oies debieron mantener más o menos puro su argumenrepresentar a lús persona podrían explicarse la semejante manerc de través de varios períodojes y sobre todo, que el Mito se conservara a

Debe rememoriodos hasta la llegada de los españoles.

natural de hondarar un importante acontecimiento, o algún fenómeno el tenor de las leyendas recón que influyó aún en sus creencias. Por les arqueológicos, podría sumidas por los Cronistas y por los materiaCiltural de origen Ecuatorial a yo caso simbolizaria a la Corriente del las condiciones meteorológicas de la costa que periódicamente altera apoyado por los numerosos testimonios arqueruana. Lo primero zstaria la difusión de elementos culturales pros arqueológicos relacionacios con empleo de tembetas, tarugos, dos de plumas de aves tropicabiales, orejeras con conchaperla, vesti- 
hecho de que en los testimonios arqueológicos el Dios siempre está asociado al mar, en materias primas cuyo uso parece haber sido introducido simultáneamente con su culto como las conchas tropicales: Strombus, Spondylus y Madre Perla, la Turquesa; el lapizlázuli. En muchas representaciones el Dios emerge de dichas conchas como espíritu protector; en otras, preside flotillas de balsas o realiza personalmente la pesca del tiburón, de la manta y otros seres que son extraños a la Corriente de Humboldt.

En las leyendas el personaje central recibe nombres diferentes, siendo los más comunes el de Naylamp y Quitumbe.

La imagen de este- Dios en todas las culturas mencionadas tiene rasgos bien definidos que lo distinguen de los otros dioses; es semejante en todas ellas, variando sólo en la mayor o menor complejidad de la representación, y en la presencia o ausencia de ciertos seres del medio geográfico. Adopta generalmente figura humana; pero propiamente es la humanización de un ave con copete de plumas en la cabe$z a, 10 j o s$ rasgados ribeteados de oscuro, rostro manchado lateralmente, alas y plumaje salpicado de pintas; elementos estructurales que se conserva en la mayoría de las representaciones.

En el Arte de Ancón afecta figura francamente femenina; con' los senos y sexo bien marcados; y generalmente con pequeñas alas en vez de brazos; y con el copete de plumas transformado en amplio tocado similar. Está representado profusamente en los figurines de arcilla conocidos con el nombre de "cuchimilcos" y en escudos ceremoniales pintados que acompañan a los fardos funerarios. Este Dios de Ancón es el mismo que figura en el arte Chimú y en los Idolos de Batán Grande, lo que revela que su culto fué generahy se extendió por la costa hasta muy al Sur, tal vez hasta Chincha, en cuya cerámica igualmente está representado comoguna umujerelli Converso"

Tal Dios que tiene como origen un ave se convierte en el de mayor importancia en el Norte. Mereció un culto fastuoso; se le levantaron templos con bajo relieves y pinturas murales; y se le ofrecieron ofrendas y sacrificios. Su imagen fué reproducida en diversas materias así en madera, en arcilla, en los tejidos, en piedra y muchas veces en oro como los ídolos arriba mencionados y en este caso ataviada con lujosos vestidos $\mathrm{y}$ joyas y revestida con atributos y símbolos de su poder.

En los testimonios arqueológicos se le ve asociada al Mar; a las zonchas marinas de origen tropical; a las escenas de pesca; y principalmente asociada a las Islas que eran su residencia habitual. En estas islas habían adoratorios y personal de su culto; lo sabemos a través de las crónicas y de los propios huacos que reproducen con toda fidelidad los Islotes con sus características aves guaneras; sus lobos etc.; y allí figuran también: el sitio de adoración, los guardianes que custodian el adoratorio, y escenas en las que participan la "pareja divina" y otros seres cumpliendo un ceremonial relacionado con la fertilidad y aumento de la producción. 
Los cronistas consignan imporiantes datos acerca de este culto y mencionan los nombres de algunas islas como la de "La Plati" en donde, según Xámano, enconiró Pizarro un bellísimo adoratorio con la imagen de una diosa femenina con un niño en brazos y muchas ofrendas de oro y plata en forma de brazos, piernas y otros miembros humanos. Se hace referencia en otros documentos a que en dicha isla y en la de Santa Clara, Puná, San Lorenzo elc., solían enterrar a los señores principales.

La importancia de las islas como lugar de residencia de la diosa femenina, o diosa Luna, está claramente demostrada en las representaciones de la cerámica peruana, principalmente de la Muchik y Chimú. El Dios solo terminaba su diario recorrido en la isla en donde se realizaba el romance amoroso de la pareja divina. En muchos huacos está ilustrada esta escena en la cual solícitamente intervienen gaviotas, perritos, un zapo y cóndores, estos últimos, encargados de tras. portar en sus alas al dios Sol.

En las esculturas líticas y en la cerámica de Manabí en la alfarería Muchik, en los teidos y en la alfarería de Huaura y Chancay, existen numerosas representaciones que ilustra el $\mathrm{M}$ i t o motivo de este estudio. Pero donde se encuentrar los más completos elementos es en el arte de la cerámica y de la orfebrería Chimú.

\section{Registro del Mito en los lestimonios arqueológicos de las Culturas del Norte del Perú.}

En el capítulo anterior se ha hecho una apreciación de los documentos históricos reiacionados con este Mito, ahora se presentan los testimonios arqueolócjicos en los que se apoyan propiamente las conclusiones de este trabajo.

Muchos pasajes del Mito están registrados en la cerámica, en los tejidos y aun en las joyas y prendas personales; y a través de éstos se descubre que el hombre a falta de escritura se sirvió de estos medios para perennizar acontecimientos históricos producidos en épocas lejanas $\mathrm{y}$ cuyo recuerdo era necesario mantener. Además el carácter mítico que tienen los personajes de esa historia y los atributos que ostentan revelan que la fantasía popular los dotó de cualidades extraordinarias que. respaldaban la importancia de sus hazañas. Por otro lado algunos de sllos eran tan poderosos que podían desencadenar tempestades, lluvias, terremotos y otros fenómenos ostentosos que impresionaron al aborígen; y esa capacidad de poderlos producir estár simbolizada por ciertos emblemas y dibujos que tienen un significado específico que comienza a descubrirse.

A fin de reconocer al Díus, que es el protagonista de este Mito, y a algunos de sus auxiliares se les describe aquí en rasgos generales.

Está representado casi siempre en forma humana pero posee ele. mentos ornitomorfos que demuestran que se trala de un Ave Humani- 
$-189-$

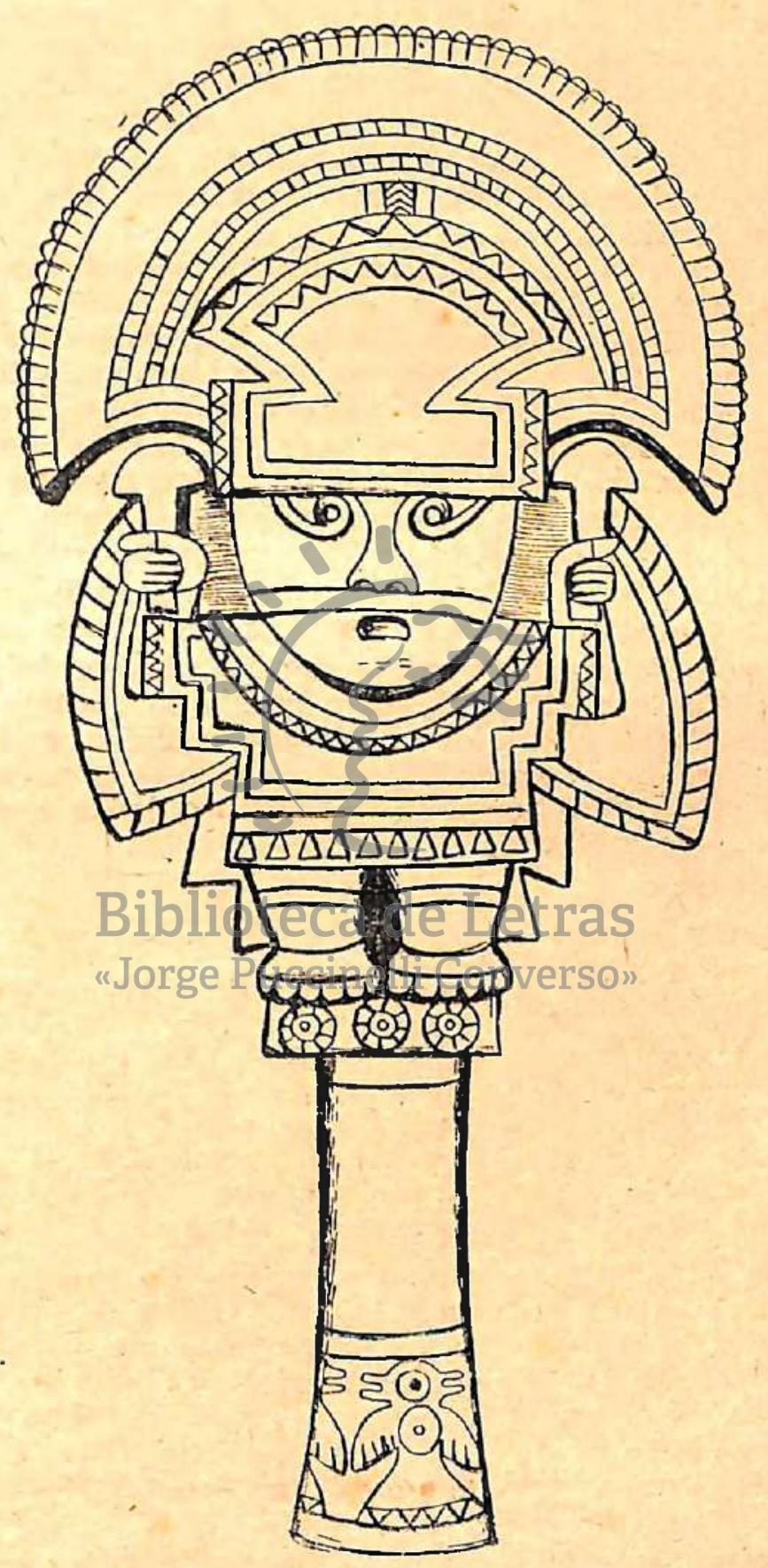

La Diosa Luna - Ornitomorfa. 
zada. Estos elementos son las alas, el copete de plumas sobre la cabeza sustituído por un vistoso tocado de forma semilunar o semiesférico; los ojos rasgados con mancha ocular; el rostro pintado lateralmente; y el cuerpo salpicado o no de manchas perladas. (Lam. I.)

Este Dios en sus representaciones más antiguas es un Ave casi realista a la que se le dota paulatinamente de diversos adornos que lo alejan del modelo primitivo, como puede apreciarse en algunas piezas de la orfebrería Chimú.

En períodos posteriores las representaciones se hacen francamente humanas como ocurre en los modelos de Chancay y Ancón, perteneciendo a este tipo alejado el llamado "Cuchimilco" o figurín que representa a una mujer desnuda con el sexo bien marcado pero que conserva como símbolos divinos las alas y el copete de plumas.

A pesar de las diversas modalidades locales que alcanza este personaje, es posible reconocerlo sin dificultad gracias a la persistencia de esos elementos y a que sus actividades están siempre asociadas al mundo misterioso del mar; a los animales y moluscos marinos.

Indudablemente se trata de un ave de gran importancia en las creencias populares; de un ave de costumbres nocturnas o de aparición periódica; de alguna gaviota extraña al Litoral del Pacífico que venía con la Corriente del Niño junto con la fauna tropical compuesta por el tiburón, la manta y las conchas spomdylus y strombus. En mi trabajo "La Luna y su personificación ornitomorfa en el Arte Chimú" esbocé esta teoría; que hoy amplío gracias a la existencia de un material de estudio muy rico.

Está asociado:

$$
\begin{aligned}
& \text { 1.- A aves guanerasinelli Converso", } \\
& \text { 2.- A lobos marinos o perros de cola coposa } \\
& \text { 3.- A sapitos o ranas } \\
& \text { 4.- A mujeres, que generalmente lo llevan de la mano. } \\
& \text { 5.- A seres sacrificados, de los cuales sólo aparecen las } \\
& \text { cabezas cortadas o decapitadas } \\
& \text { 6.- A la navegación marítima y a flotilla de balsas } \\
& \text { 7.- A la pesquería de perlas } \\
& \text { 8.- A la pesca del tiburón } \\
& \text { 9.- A las islas guaneras en las que figuran lobos, aves, y } \\
& \text { el dios dirigiendo la pesca del tiburón y la manta } \\
& \text { 10.- A los templos y adoratorios en los cuales aparece cus- } \\
& \text { todiado por dos auxiliares. }
\end{aligned}
$$

\section{El Mito en el Arte Chimú}

En la Cultura Chimú es donde se encuentran los más abundantes testimonios relacionados con el culto astral a la Luna y con los diversos elementos que componen el Mito Norteño. Ya en mi trabajo preliminar sobre "La Luna y su personificación ornitomorfa" hice una pre- 
sentación de los principales elementos descubiertos entre los materiales artísticos.

Nuevos y valiosos datos han sido obtenidos con la incorporación de recientes colecciones Chimú ingresadas al Museo, y con el estudio de las magníficas colecciones del Museo Brunning y de otras en poder de particulares. Ellas han sido objeto de un trabajo hondo de investigación, cuyos resultados se darán a conocer en una obra dedicada a ese acerbo científico.

Aquí sólo me limitaré a hacer algunas apreciaciones generales y a presentar unas pocas ilustraciones sobre el tema.

Existe una área arqueológica bien definida que, por sus manifestaciones artísticas homogéneas y coordinadas, puede ser calificada con toda razón como área Chimú y cuya expansión territorial puede señalarse sin dificultad alguna, por la expansión de sus elementos artísticos que en toda ella es igual o semejante.

Dos focos de alto desarrollo presenta esta cultura Chimú: una en Lambayeque y otra en Chanchán, y en ambos este desarrollo está representado principalmente por $\in$ l adelanto de la orfebrería en oro y plata. Las más excelentes obras metalúrgicas provienen del área Chimú, en donde los virtuosos han dejado las pruebas evidentes de su habilidad y pericia para técnicas muy avanzadas tanto de fabricación como de procedimientos de soldaduras, baños, etc.

Simultáneamente con el desarrollo de la orfebrería, la arquitectura alcanza también sus mejores creaciones. Es el área de los grandes Templos y de las pirámides dedicadas al culto de los Dioses más espectables de su Mitología y los mejores y más suntuosos de ellos estuvieron precisamente dedicados a la Diosa Luna, protagonista del Mito Cultural.

Los más suntuosos templos o huacas de Lambayeque, Motupe, Túcume, etc., estuvieron adornados con pinturas murales con las imágenes de este Dios, tal como aquella denominada "Waka Pintada". Y en las sepulturas descubiertas en su interior y en los alrededores, se han encontrado valiosas joyas de oro pertenecientes a la clase sacerdotal o a altos dignatarios adornadas con representaciones de dicha divinidad y de los seres que eran sus auxiliares. $A$ este respecto merece mencionarse el hallazgo de Batán Grande, Illimu, compuesto de grandes ídolos de oro, orejeras, vasos de este metal con incrustaciones de turquesas.

Asimismo en las principales huacas de Chanchán como en la de La Misa, han sido exhumadas artísticas piezas de oro, consistentes en cálices calados, orejeras, collares y discos de oro y plata, adornadas casi en su totalidad con las mismas imágenes de la diosa.

Es extraordinaria la importancia que todo un pueblo y una civilización dió a un asunto de carácter mitológico, como si en su historia no existiera acontecimiento de mayor interés que éste. Apreciadas las cosas con criterio moderno, parece inexplicable que todo el arte sea tan homogéneo e inspirado en un solo tema. 
Por consiguiente debe tratarse de un acontecimiento histórico que cambió sustancialmente la vid $x$ del pueblo Chimú; 0 bien de tremendos cataclismos provocados por fenómenos naturales, que destruyeron poblaciones y arrasaron con la agricultura que era su principal soporte económico; y como consecuencia de ella surgió una religión que en el fondo era síntesis de sus angustias y temores, cristalizada en el culto a dioses protectores de la vida y de los recursos.

Aun la propia ciudad de Chanchán viene a ser una ciudad santuario que en cada barrio o cuartel tiene una o dos huacas; y los preciosos arabescos y bajo relieves que adornan las paredes de los palacios tienen como tema principal los mismos que figuran en la orfebrería y en la cerámica. Es una misma Historia registrada en los paramentos murales; y aquí como se dispone de mayor espacio, las escenas son más complejas y por ende más ilustrativas.

El examen que he hecho de estos bajo relieves de Chanchán y su comparación con lo que se encuentra en las artes menores, me ha conducido al descubrimiento, que acabo de exponer, de que todas las obras de un pueblo, y de una edad están dedicadas a perennizar acontecimientos magnos de su historía.

No sólo fué registrada dicha Historia en la forma anotada, sino que fué celosamente conservada por el cuerpo sacerdotal a través de los períodos siguientes, de evolución histórica pues se encuentran muchas de las imágenes en el arte posterior, aunque se han perdido elementos de importancia.

La propia palabra Chanchán, es una alteración de la palabra Shian Shi-an, cuya primera sílaba Shísignifica Luna, S Shina que es una designación semejante. Y si analizamos los términos con que designan los diversos templos" $y$ personajes femeninos de Pás leyendas trasmitidas por Cabello Balboa y por Anelo Oliva, encontramos la repetición de este concepto. El primer templo que funda el héroe cultural Naymlap es Chot, posiblemente Shiot; el primer sucesor de Naymlap es Cium o Shi-un, origen de toda una dinastía de reyezuelos.

La primera pareja de carácter divino que da origen, en la leyenda de Uliva, a la dinastía de los Inkas del Cuzco es Guayanay y su esposa Sigar, es decir Shi-gar, que precisamente es símbolo de las islas en dicha leyenda.

bién $Y$ si analizamos el nombre del gran reino del Chimú, aquí también vuelve a intervenir nuestro sufijo Shi-mu, indicativo de Luna.

Muchos otros ejemplos encontramos en los nombres y en los personaies míticos de más al Sur. El templo de Shi-mu Capac en Casma; la isla de San Lorenzo o Shi-almerina; y más al Sur las célebres islas de Shi-incha (Chincha) y la de Shi-ancayan o Sangallan frente a Paracas. Esie ligero análisis pone de manifiesto que hubo un culto generaì a la diosa Luna; y que principalmente las Islas y las grandes ciudades-santuarios estaban dedicados a este Dios o recibían el nombre de él como expresión genérica. Aun la tradición posterior a la Conquista hace alusión al Pez Grande y al Pez Chico, símbolos de este Dios. 
Un ejemplo del mayor interés relacionado con este culto es el que ofrece el Templo llamado arbitrariamente "El Dragón", situado a la entrada de las ruinas de Chanchán. Es un pequeño santuario dedicado a la Luna; todas sus paredes están decoradas con preciosos bajo relieves pintados con escenas de la Diosa Luna, en conexión con sus actividades relacionadas con el mar, con las aves guaneras y con los peces y otros seres marinos. Y en las excavaciones practicadas en su interior se han encontrado sepulturas conteniendo cadáveres de mujeres jóvenes. Estos pueden corresponder a entierros de personas del sexo femenino dedicadas al culto; o bien a casos de sacrificios humanos, que es poco probable. Además fueron encontrados algunos ídolos de madera con imágenes mitológicas que he examinado y corresponden a representaciones de la misma divinidad lunar.

Sólo como ejemplos del rico arte religioso Chimú, se colocan a continuación algunas ilustraciones de las actividades y funciones del Dios Lunar; y de preferencia para mostrar su conexión con la Corriente marina del Niño, con las conchas tropicales, y con las aves marinas y peces.

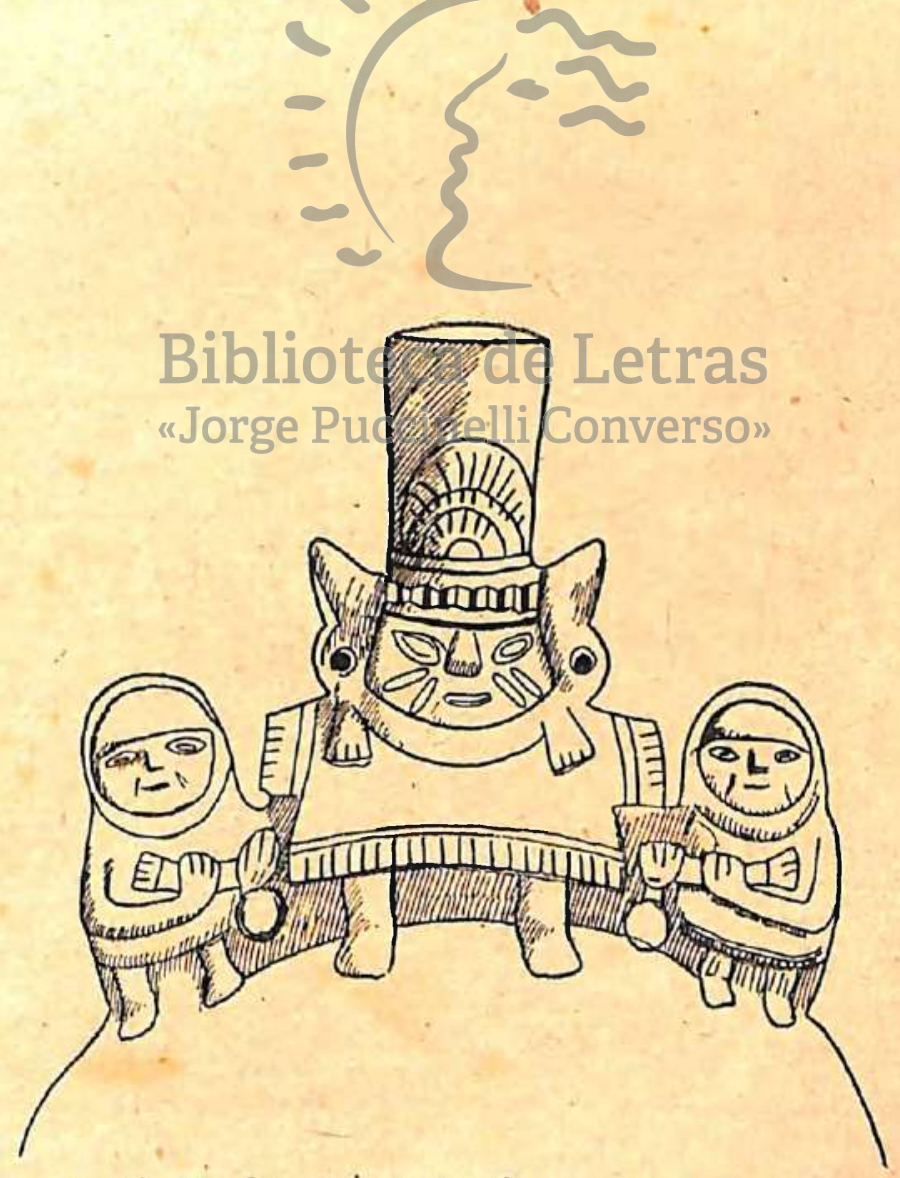

La Diosa y las mujeres que le acompañan - Trilogía. 

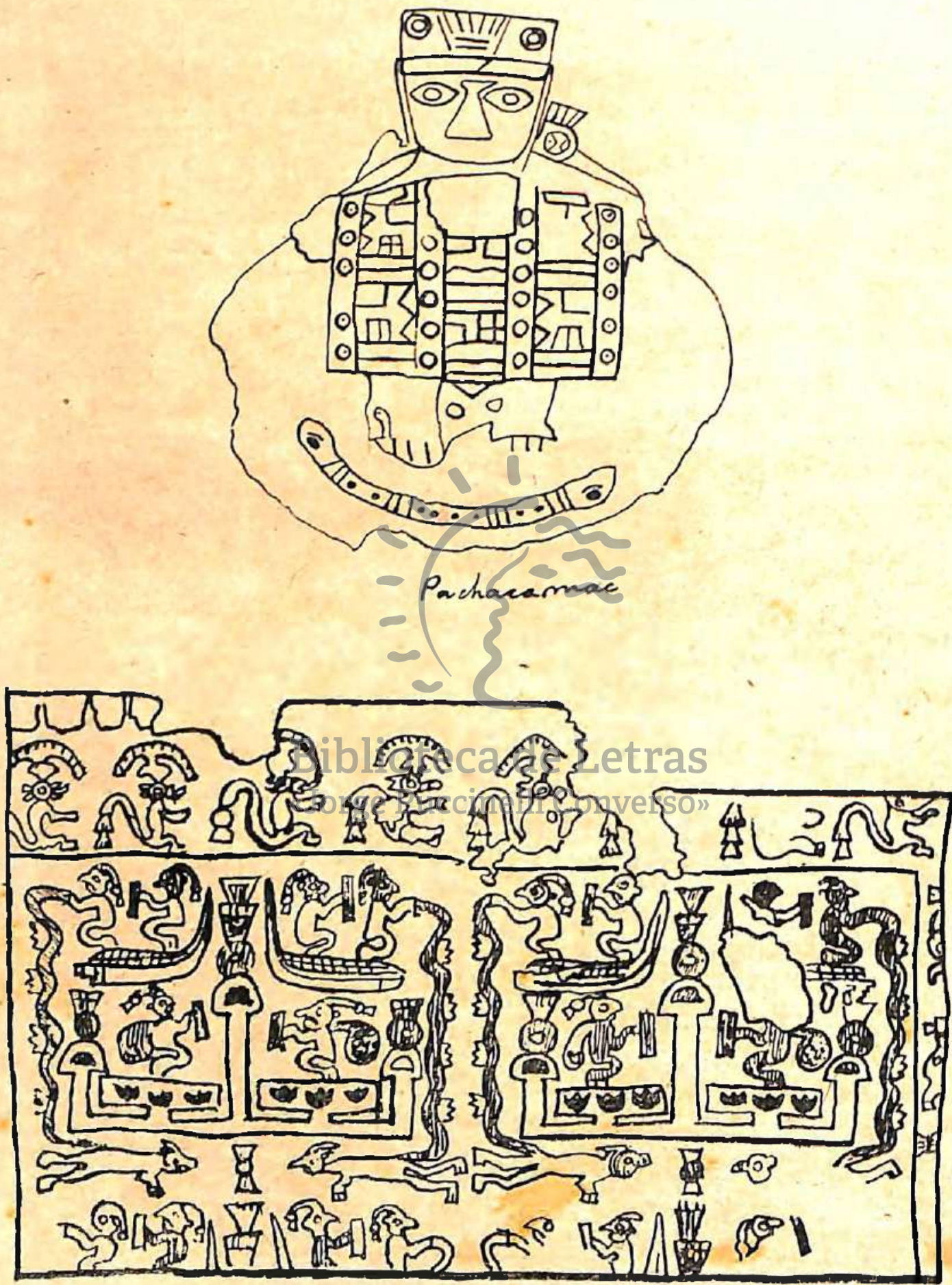

La Diosa y las conchas tropicales. 


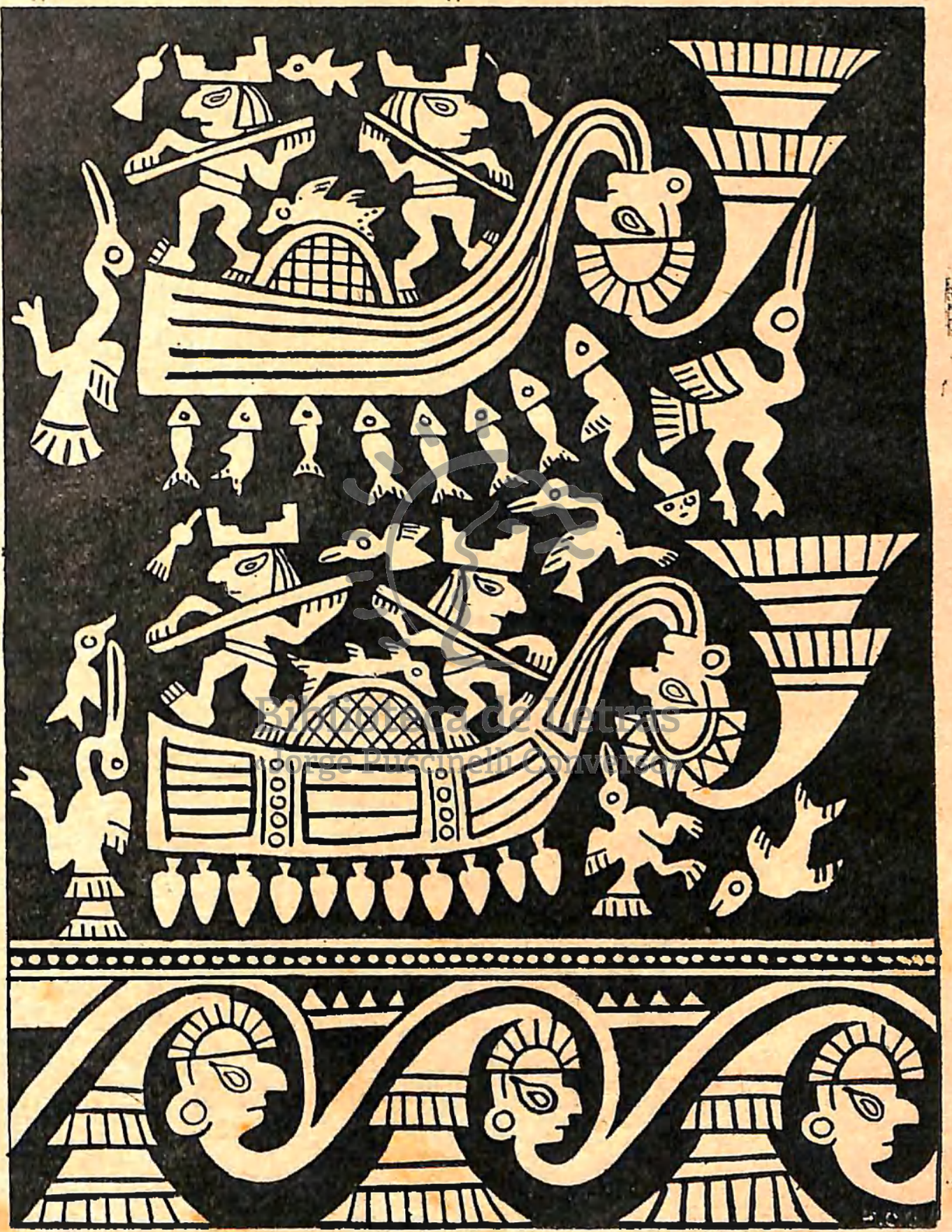

La Diosa y las flotillas de balsas. (Como refiere Cabello Balboa). 


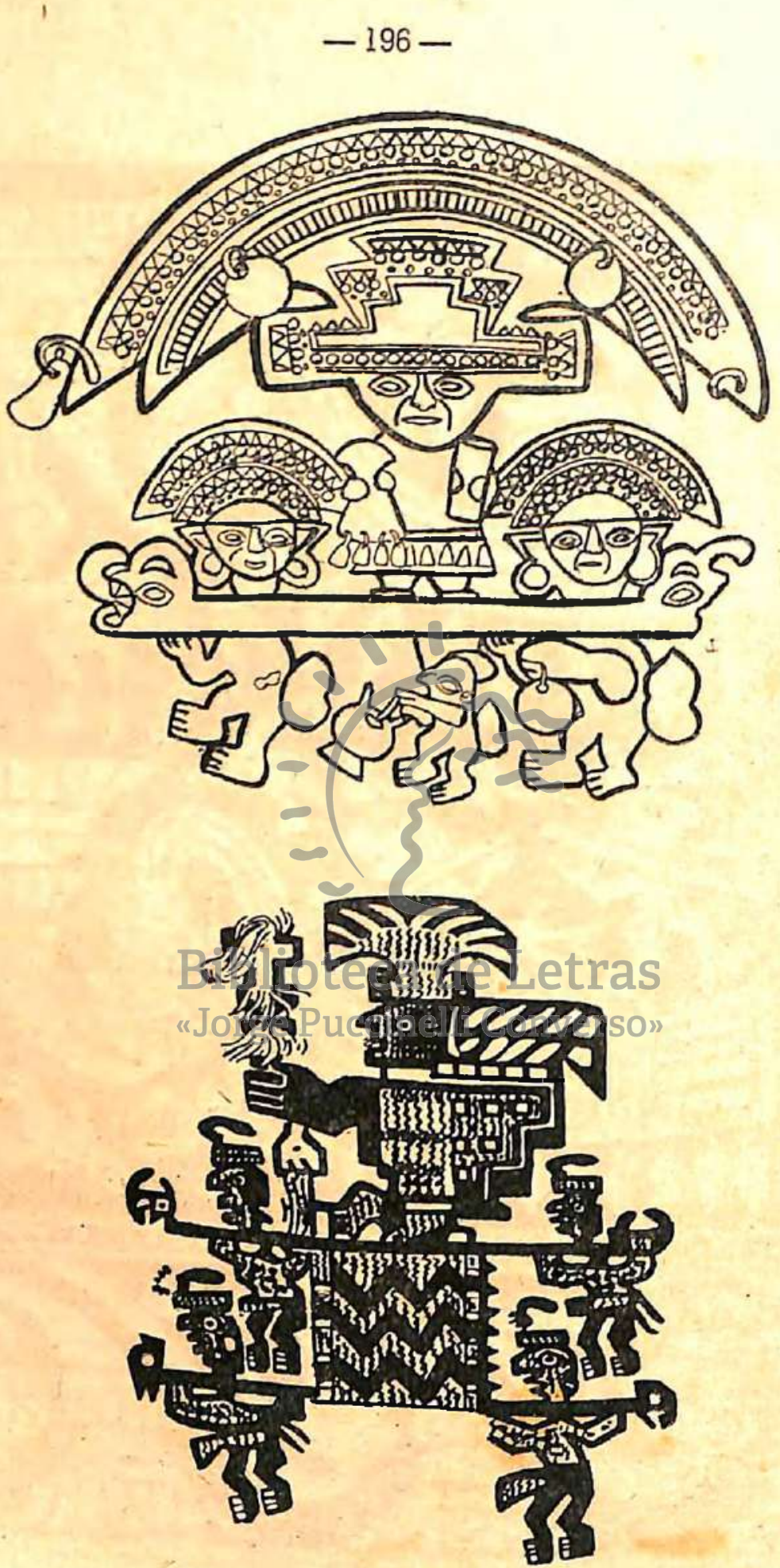

1

La Diosa transportada en andas y literas. (Puede apreciarse la gran semiluna en la cabeza). 

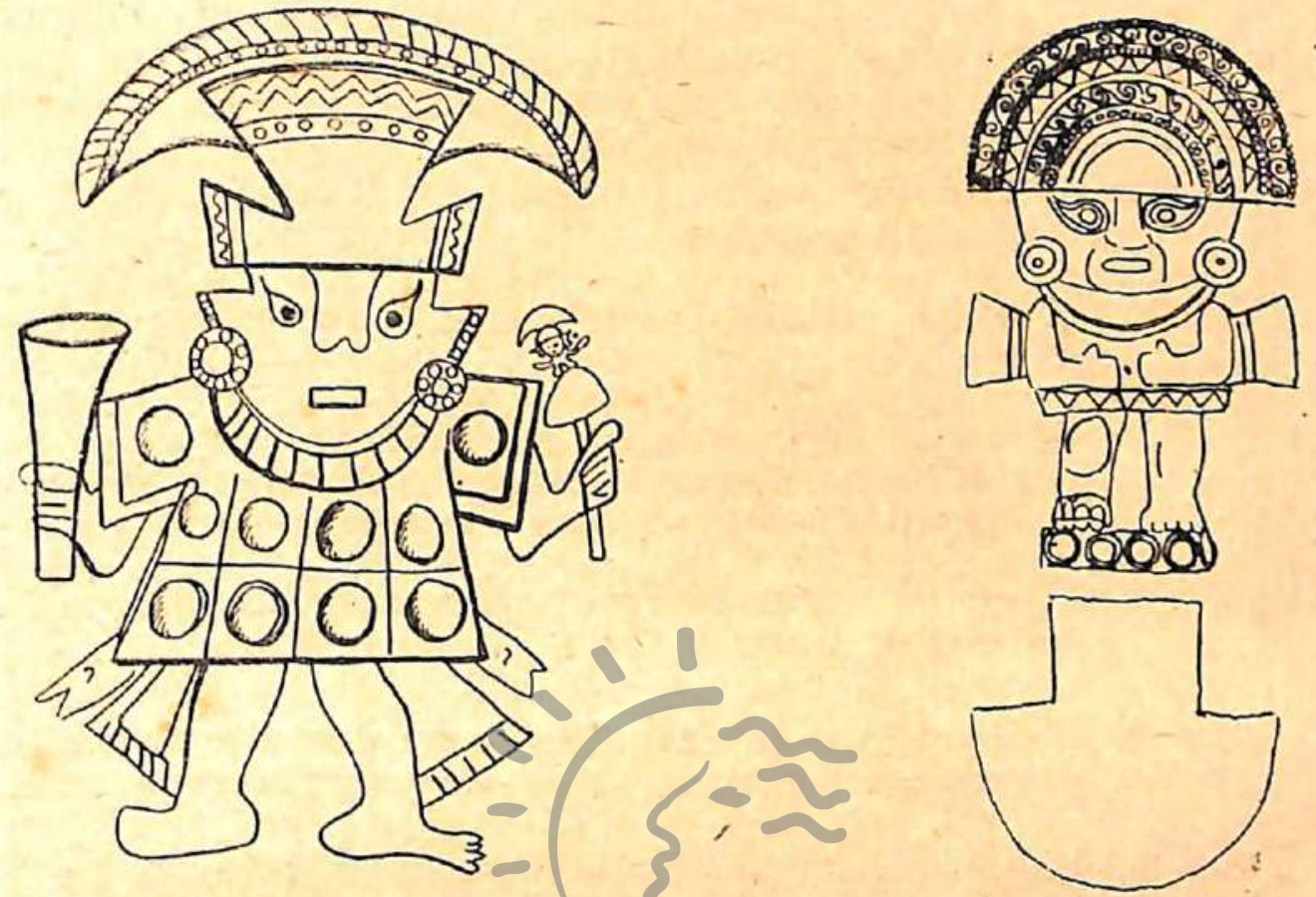

La Diosa en su función sacrificadora; con copas o vasos para la sangre.

\section{Biblio Conclusioneș etras}

A través de las fuentes estudiadas: historicas y arqueológicas se llega a las siguientes conclusiones generales:

Que existen pruebas suficientes acerca de dos problemas del mayor interés:

1.-De la existencia de interrelaciones e influencias culturales entre los pueblos del Norte del Perú con los situados más hacia el Septentrión. Dichas influencias se han producido en períodos diversos y están acompañadas con la introducción de materias primas exóticas al Perú.

2.- Y que en edades pasadas se produjeron en el territorio peruano cataclismos de grandes proporciones provocados por fenómenos diluviales, tempestades, terremotos, erupciones volcánicas, etc. que asolaron a las poblaciones y obligaron a abandonarlas y a ocupar otros lugares.

Y como consecuencia de estos acontecimientos el aborígen creó concepciones cosmogónicas propias; creó dioses protectores o adversarios; y en fin dejó, en sus tradiciones y leyendas, registrados sus pensamientos de temor y de inquietud ante hechos que no podía dominar. 
El primero, esto es las influencias culturales, está acreditado por los testimonios de dos claras influencias: una Chimú muy extendida cuyo límite Norte podría estar en Manabí y su límite Sur en Pachacamac; y otra de origen ecuatorial o tal vez Chibcha.

La primera influencia está representada por el común empleo de ciertos elementos culturales como:

a.-El uso de orejeras de madera con incrustaciones de concheperla.

b.-El uso de adornos de oro ejecutados en técnicas de filigrana, calado y vaciado; representado por los hallazgos de orfebrería hechos en Chanchán y en Batán Grande.

c.-El uso de plumas de aves tropicales en la confección de prendas de vestir.

d.- Y en el campo de la arquitectura por el empleo de adobes pequeños rectangulares y bajo relieves, y pinturas murales. siguiente:

La influencia ecuatorial o septentrional estaría representada por lo

a).-La introducción de materias primas exóticas al Perú, de origen marino y mineral, como-las conchas tropicales spon. dilus y madre perla, la furquesa y el lapislázuli.

b.-Por la existencia de un continuo comercio marítimo, sostenido desde épocas antiguas, de estas materias primas para su utilización principalmente en la manufactura de objetos del ritual religioso o funerario.

c.-En el establecimiento de ciertas costumbres y fomentos de artes que no eran propios de los pueblos del Norte; como:

1.-El uso de la tembeta "o quillashinga".

2. - El uso de adornos labiales en forma de tacos o pequeños tarugos de concha, turquesa u oro. (Como los hallados en Tumbes por Petersen; y las representaciones sobre este tema en la cerámica).

3.- El uso de tatuajes incididos en el rostro y aun tal vez las pinturas de la cara. (hecho que está ilustrado en la Leyenda de Naymlap).; y en los huacos retratos Muchink. 
4.-El uso de gargantillas, collares o pectorales de varias hiladas; hechos con conchas o con cuentas de este material. Uso que se extiende hasta Ancón por el Sur.

5.-Uso de figurines, sonajas para los fines rituales.

6.-Tal vez el entierro horizontal también puede venir con dicha corriente.

Los aportes culturales ofrecidos por estas dos influencias provocaron lógicamente mestizajes; prestaciones y modificaciones a veces sustanciales en las culturas receptoras.

Tales influencias están claramente establecidas por las propias tradiciones de Cabello Balboa y Anello Oliva. La primera como se ha visto al hacer su análisis en el Capítulo I, hace referencia a varios linajes de origen septentrional establecidos en el área de Lambayeque; y a otros linajes locales; que alternadamente se sucedieron en cinco períodos. Y mucho más claras son esas interrelaciones a través del material arqueológico: en los restos de Huaura; Chancay o Ancón se encuentran elementos culturales típicos del Chimú, como las orejeras de madera con incrustaciones, que parecen ser exhumadas en una sepultura Chimú y no en una sepultura de Ancón; y así en cuanto a los elementos traídos con las culturas ecuatoriales.

Ahora en cuanto al segundo problema de los cataclismos que conmovieron este territorio; quedan pruebas evidentes de ellos en muchos sitios del Perú y principalmente en la Costa. Evidentemente debieron producirse deglaciones y lluvias torrenciales que produjeron fenómenos ostentosos como los aluviones, las avalanchas, las inundaciones, etc. Pueblos prósperos del Litoral peruano fueron destruídos por estos fenómenos. Como ejemplo de ello, sólo recordaré aquí, los hallazgos de Ñepeña y Sechín en los que se encontraron templos y otros edificios sepultados bajo gruesas capas de lodo y grava. Las estelas de Sechín en número de 89 habían saltado de sus cimientos y arrojadas a algunos metros de distancia. Y si nos trasladamos a Wari Ayacucho allí también veremos los restos de un templo lítico completamente destruído y sus piedras oscuras diseminadas. Y cosa semejante ocurrió también en el interandino ecuatoriano; allí han sido encontrados restos de templos bajo capas volcánicas. Chavín de Huantar periódicamente sufrió los efectos de waikos; y Pukará el más antiguo está asimismo debajo de capas de grava.

Las tradiciones obtenidas a raíz de la conquista son muy elocuentes sobre este particular; y en todas las recogidas más tarde, figuran luchas de dioses que desencadenaban la furia de su poder simbolizada por lluvias, tempestades, etc.

De aquí que los mitos que explican la creación del Universo indio, del hombre, de los frutos y de los animales, estén envueltas en este sentimiento de respeto y temor hacia lo que no puede dominarse. De aquí también el que figuren constantemente creaciones y destrucciones; que figuren los huevos cósmicos, forma postrera de dar nueva vida y crear 
a la Hurranidad y a los recursos de que ha de sustentarse, y que figuren símbolos de la corriente del Niño que cambiaba periódicamente la faz de la Costa.

Los Dioses como el que figura en el Mito de Norte es uno de los más importantes, es la Diosa Luna que radicaba en las Islas; que gobernaba las mareas, los temporales; pero en una palabra era el símbolo del argua que vivifica; del agua que riega los crmpos. del mar que ofrece todos sus recursos al hombre. Por ello la vemos representada en el arte del Norte siempre asociada al mar o a los estanques o lagunas que son los lugares sagrados de donde arranca la vida; donde existen los gérmenes que dan nacimiento a los recursos del hombre.

La Diosa Luna en la cerámica y en los tejidos figura.surcando el océano en su barca semilunar cargado de recipientes de agua; o asociado al símbolo del agua de lluvias que allí está representado por una voluta o signo en forma de S. O bien en la Isla guanera donde varios de sus agentes recogen el guano y lo colocan en botes para ser trasportados a la costa y transformar los campos desérticos en fértiles y feraces.

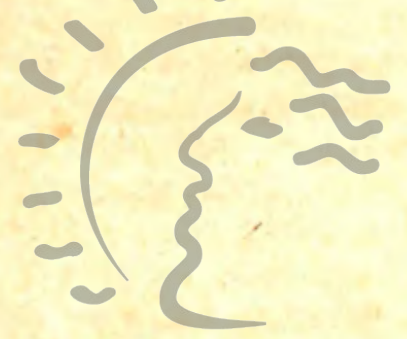

\section{Biblioteca de Letras "Jorge Puccinelli Converso"}

